\title{
Plato on Political Stability: Some Lessons for Nigeria
}

\author{
M.O. Olatunji \\ Faculty of Education, Ajayi Crowther University, Oyo, Nigeria \\ lekanolatunji48@gmail.com
}

\begin{abstract}
The Greek world during the time of Plato was characterized by political challenges and pronounced social injustices. There were turmoil and party conflicts. Plato saw Greece of his time as a place that was very difficult to govern properly because of opposition from those who were bent on putting their own interest above that of the state. Plato saw most of the politicians of his time as selfish. There was violence and party struggles and the eventual defeat of Athens by Sparta and other members of the Peloponnesian Confederacy in $404 \mathrm{BC}$; a defeat which Plato attributed to maladministration by the rulers. In order to change the undesirable trend of event for better, Plato came up with a series of ideas. The scenario that characterized the Greek world in which Plato lived is to a very large extent similar to the happenings in twenty first century Nigeria. This paper therefore examines the theory postulated by Plato as the panacea to the crisis in Greece of his time and draw out areas that are relevant as solutions to the socio-political challenges facing Nigeria in the twenty first century. The paper adopts a blend of Critical Theory, Historiography and Philosophical analysis as its research methodology and concludes among other things with a clarion call to address headlong the obvious leadership challenges that have been the $\operatorname{cog}$ in the wheel of the Nigeria's progress for years.
\end{abstract}

Key words: Plato, Stability, Nigeria, Athens, Morality, Greek

\section{Introduction}

No one has ever equaled Plato in the voyages of intellectual discovery and adventure [Brumbaugh, 1974]. Plato was born in 427 B.C., the son of Ariston and Perictione, both of whom were descended from distinguished Athenians of royalty and were well to do. His father died when Plato was a few years old. The Greek custom like what operates in most part of the contemporary world allowed his mother Pericitone to re-marry. Plato's step father, Pyrilampes, was a prominent Athenian. He had been a close friend and supporter of Pericles [Jane, 1994]. Socrates frequented Pyrilampes' home for discussion. As a result of this, Plato over time developed interest in Socrates and his philosophical ideas. Plato grew up in a period of political crisis. The Peloponnesian war began before he was born and lasted until he was 23 years old. The war involved Athens on the one hand and Sparta together with the other members of the Peloponnesian Confederacy on the other. The war ended on a bad note for Athens in 404 B.C. With the fall of Athens, a commission of thirty men was set up to produce a new constitution. In the interim, the Thirty governed Athens. They however ruled with iron hands and this degenerated into internal conflict as the Thirty used their new found opportunity to settle old scores. There was anxiety, party bitterness and uncertainty. Morality was at very low ebb, essential traditional values were overlooked, the rule of law was greatly abused, and there were injustices. Plato saw the Athens as a place that was extremely difficult to govern properly and that the defeat that was suffered in the Peloponnesian war was as a result of mal administration and mutual distrust among the leaders. When the masses could no longer bear rule of the Thirty, there was an uprising that eventually led to the Thirty been driven out of government and all of them killed. This incident was followed by a very short period of relative sanity in Athens during which Plato contemplated the idea of taking very active part in the politics of Athens. However, in 399 B.C., Socrates, whom Plato greatly admired and seen as "the most upright man then living", was condemned and executed by politicians on a charge of impiety and corrupting the youth, Plato became more convinced that Athenian society was politically too corrupt, ignorant of the nature of man, and particularly wrong in condemning Socrates. For these reasons, he abandoned his interest in politics and took to philosophy and the search for solution to Athenian leadership challenge. Some scholars maintain that Plato served as the "defense attorney" for Socrates during his 
trial. That he lost the case, coupled with the fact that his beloved mentor had a profound effect on him made Plato anxious to preserve the memory of Socrates [Hare, 1999]. Following the way Socrates was brutally exterminated, Plato dedicated his life to the vindication of Socrates' memory and teachings and also the presentation of his own theory on how society can be properly governed. He wrote 34 dialogues, with The Republic in the middle. It is of general consensus that the first dialogues written by Plato were the immortalization of his mentor's thought, and also a distinctive Socratic Philosophy. Beginning with the Republic and the following later dialogues a Platonic philosophy and philosophy of education was outlined.

According to Korab- Karpowicz (2016), Plato developed such distinct areas of philosophy as epistemology, metaphysics, ethics and aesthetics. He alludes further that the deep influence of Plato on Western philosophy is asserted in the famous remark of Alfred North Whitehead: "the safest characterization of the Western philosophical tradition is that it consists of a series of footnotes to Plato".Korab-Karpowicz, (2016) also observes that Plato was an ideal political philosopher whose ideas had a profound impact on subsequent political theories. His greatest impact was Aristotle but he influenced Western political thought in many ways. The Academy, the school that Plato founded became the model for other schools of higher learning and later for European universities. It is the view of Plato that the interest of different parts of society can be harmonized. Korab-Karpowicz (2016) argues that the best, rational and righteous, political order which Plato proposes leads to a harmonious unity of society and allows each of its parts to flourish, but not at the expense of others. Plato however points out that the theoretical design and practical implementation of the order he proposes are impossible without virtue.

Plato criticized the politicians of his days for being ignorant and incompetent. He criticized them for their violence, selfishness that was manifested in party struggles with the different factions placing their own interest above the interest of the state. Plato saw the disparity of economic interests between those who had property and those who had none as the main reason factionalism and party selfishness. Even in the smallest city, Plato saw that there were, in fact, two distinct cities - "a city of the rich and a city of the poor, externally at war with each other [Sabine, 1973]. Plato was grieved by the situation in Greece as he saw that public action can only be carried out successfully only with the availability and support of trustworthy supporters. Such was the society in which Plato lived. He was therefore convinced that mankind would have no respite from trouble until something drastic was done to halt and redirect the dangerous trend of events then. He believed that hope could come about only when real philosophers succeeded in gaining political powers or until, through divine intervention, those who rule and have political authority become real philosophers. These should be persons who love wisdom and truth, who must study and distinguish themselves in their understanding of the basic nature of true existence. To some extent, many of the conditions that Plato lamented about in his days are prevailing in $21^{\text {st }}$ century Nigeria. This reality motivated the thought that some of Plato's recommendations may give insight on how to solve some of the major challenges facing Nigeria today.

\section{Methods and Conceptual Clarifi- cations}

Political Stability is a major concept in this paper. Attempt is therefore made to examine it and come up with the context within which it will be used in the discussion.

Political Stability is a relatively permanent social arrangement within which both the affairs of the state and the conduct of all aspects of social life, spiritual, cultural and economical, can go on without fear of disruption or threat either from within or from outside aggressors [Bamisaiye, 1998]. Political stability therefore becomes both an aspiration and a value in the modern state. It is an aspiration without which a state cannot exist. Bamisaiye, (1998) explains further that political stability is a value necessary for the attainment of the good life for the people living within her borders. She gives some factors that make for political stability. These are:

\section{Social Order and Control}

Social Order is the absence of chaos while social control is the prevalence of established agencies responsible for the smooth working of the machinery of state. Order is a state of affairs brought about by effective control of the apparatus of state over social life. Where there is 
lack of or ineffective control, disorder sets in. On the contrary, a situation of relative permanent means of social control leads to a permanent state of order or predictable functioning of the machinery of state. This situation of relative predictability is necessary for meaningful planning to take place. The economy is a vital social institution that needs order and control to flourish for the common good.

\section{Heritage of political tradition}

Political stability is borne out of a heritage of political tradition. A state can be said to enjoy political stability if it has consistently practiced a certain form of governance by mutual agreement and according to laid down principles agreeable to all. Where a leader cannot leave office unless he is removed by a coup, assassination or impeachment, one cannot talk of political stability. In order words, governance can be stable but be the business of an oligarchy or an autocrat.

Political stability therefore derives from strength and integrity of a serving regime as manifested by the extent of support and approval it receives from its citizens and the extent to which social unrest, violence and strong challenges to its policies and the corporate existence of the nation is absent [Briggs, 2018].

\section{Plato's Theoretical Framework for Polit- ical Stability}

In order to produce intelligent and wise rulers, Plato (1955) recommended a unique educational system. He proposed a system of education in citizenship which will be rigorous and continuous. The essence of the training would be to enable the rulers and the followers to place civic welfare above everything else. It will involve a process of selection and elimination at different levels.

Plato considered that pupils who lacked the capacity for rigorous study would be made to drop during the course. The essence of the scheme is to select the most able set of people especially in their capacity for abstract thinking. To be selected the pupils would also show the capacity for devotion to public good and the capacity to avoid deceit. Those who can successfully go through the programme would rule the state. Propaganda would have no place in the affairs of the state. While Plato advocated that every child should be given the highest training that he or she has the capacity for, he did not support the idea of providing the education that an individual will not be able to cope with nor profit by. He however advocated that individuals with temperament, interest and ability qualified them to rule should be given the opportunity for rigorous and advanced learning. This persuasion was what motivated him to establish the Academy in 387 B.C.; the first institution of higher learning in Greece which became the intellectual center in Greece and the equivalent of the first university in the history of Europe [Murphy, 2015]. The institution continued for over 900 years until it was dissolved by Justin in 529 A.D. along with other pagan institutions [Murphy, 2015].The ultimate goal of all the activities at the Academy was to achieve philosophical truth. The method of teaching was by question and answer, argument and discussion. Plato did give some lectures but his main method was oral discussion, The Academy was established as a school for producing statesmen. It was an institution established to train model politicians.

Plato's Academy which provided a base for succeeding generations of Platonic philosophers until its final closure became the most famous teaching institution of the Hellenistic world. Mathematics, rhetoric, astronomy, dialectics and other subjects, all seen as necessary for the education of philosophers and statesmen, were studied there [Korab-Karpowicz, 2016].Some of Plato's students later became successful leaders, mentors and successful constitutional advisers in Greek city states. Aristotle came to Plato's Academy in 367 B.C. at the age of 17 and remained there until Plato died in 347 B.C.. According to Smith \& Joan (1994), Plato remained at the Academy teaching, writing and living comfortably until he died at the age of 81. During his lifetime, Athens turned away from her military and imperial ambitions and became the intellectual center of Greece. She hosted all the four major Greek philosophical schools founded in the course of the fourth century: Plato's Academy, Aristotle's Lyceum, and the Epicurean and Stoic schools [Korab-Karpowicz, 2016].It is on record that one of the astounding facts in the history of culture is that the first coherent treatise on government and education that is available in Western civilization, Plato's Republic, is the most profound. Aristotle eulogized his teacher by saying that Plato clearly revealed by his own life and by the methods of his words that to be happy is to be good. The 
educational system that Plato proposed, have the practical aim of training for citizenship and leadership; his cardinal interest is education for character [Murphy, 2015].

An important maxim proposed by Plato is: The quality of the State depends on the kind of education that the members (groups) of the state receive. To Plato therefore, the purpose of education is to help the students to grow and develop their character and ability to do good. It was the conviction of Plato that in the Academy would be politicians would be taken through the process of becoming philosopher rulers who in the footsteps of Socrates would always preoccupy themselves with asking highly fundamental questions about the nature of truth, virtue, and justice [Castle, 1964]. Plato believed that the rulers must pass through a state controlled and compulsory system of education meant to provide many forms of stringent academic and emotional training for leadership. Plato divided the programme into two major parts: elementary and higher education. The former included the training of young people up to the age of twenty which will qualify the recipient of the training to commence military service. The second aspect is for individuals (men and women) who constituted the rulers. It is the conviction of Plato that human beings would never be able to realize their worth and utilize their natural endowments maximally in the interest of the populace unless the society where they lived is that where justice is maintained. In order to shed light on his conception of justice, Plato defines society as the individual at large [Monroe, 1957]. According to Plato, the society is constituted by individuals and the cumulative characteristics of the individuals constitute the nature of the society. In both the society and the individual, Plato sees justice as the condition in which the elements work in harmony. It is also the conviction of Plato that any society is made up of classes and an ideal society according to Plato should have three basic classes namely the legislators, protectors and producers. The first class (the legislators) comprises of a small group of rulers; the philosophical class. This group know what is ideal for their society, all their actions are motivated by and directed towards the benefit and safety of the entire community, they have grown to the pure region of philosophy, as rulers, they are no longer interested in ordinary things of the world, they are totally engrossed in the contem- plation of eternal ideas, they are incorruptible. It is the conviction of Plato that the leaders are not to own any private property beyond what is absolutely necessary. He opined that the possession of private properties and nuclear families by the leaders is bad because the purpose of the state is the good of the whole and not the happiness of one class. Immediately below the rulers are the auxiliaries. Members of this class do not possess the reasoning capacity of the rulers they however possess a generous, outgoing, assertively courageous dispositions which qualify them as the citizen- subjects of the state, its defender in war, its internal guardian in peace [Dewey, 1966]. As a result of this, they carry out military, police, and executive duties under the supervision of the rulers. It is their responsibility to protect the entire society and give direction to other members of the society besides the rulers. People of appetite are meant to work and produce society's means of material existence. Elechi (2012) records that Plato argues that when each of the classes is responsible for production, security and political rule perform their duties, there will be harmony. Justice therefore entails that society determines the endowment of each member and ensures that they are placed in each of the three functions according to their endowments. This according to Elechi (2012) is outward justice. Inward justice on the other hand obtains in a situation where a man does not allow the several elements within him to interfere with one another or allow any one of them to do the work of another. Justice to Plato therefore is anchored on inward and outward division of labour, a perfect state of harmony. The three classes in Plato's ideal Republic are however not castes as membership is not hereditary. Individuals are free to attain the highest position in the state that his/her capacities, education and achievement can take him. This is premised on the persuasion of Plato that a just society always tries to give the best education to all of its members in accordance with their ability.

Korab-Karpowicz, (2016) argues that while the major parts of the Republic are devoted to the description of an ideal state ruled by philosophers, the chief theme of the dialogue is justice. He argues further that it is fairly clear that Plato does not introduce his political innovation for practical implementation. According to him, the vision of the ideal state is used rather to illustrate the main thesis of the dialogue that justice, understood tra- 
ditionally as virtue and related to goodness, is the foundation of a good political order, and as such is in everybody's interest. He points out that in the view of Plato, justice if rightly understood is not to the exclusive advantage of any of the city's faction, but is concerned with the common good of the whole political community and is to the advantage of everyone. It provides the city with a sense of unity, and therefore is a basic condition for its health. "Injustice causes civil war, hatred, and fighting, while justice brings friendship and a sense of common purpose" [Korab-Karpowicz, 2016]. In order to have a more comprehensive understanding of what justice and good political order are for Plato, Korab-Karpowicz, (2016) recommends that Plato's political philosophy be compared with his pre- philosophical insight of Solon who is referred to in a few dialogues. This according to him is because it seems highly probable that Plato was not only well acquainted with the activities of Solon but that these activities greatly influenced him.

The essence of the constitutional reforms which Solon made in 593 B.C.E.; over one hundred and fifty years before Plato's birth, when he became the Athenian leader, was the restoration of righteous order. Korab-Karpowicz, (2016) recounts that in the early part of the sixth century Athens was disturbed by a great tension between two parties: the poor and the rich and was almost at the point of going into civil war. On the one hand, as a result of an economic crisis, many poor Athenians went into debt, and since their loans were secured mainly by their own persons, thousands of them ended in serfdom. On the other hand, motivated by the profits from loans, the rich became adamant in defending private property and their ancient privileges. The partisan strife, which became obvious to follow, would make the economy of Athens weaker and also make her vulnerable to external attacks As a result of this, Solon was appointed as a mediator in this conflict. He reduced the rate of interest, effected the cancellation of all debts, and gave freedom to serfs. Though he acted moderately and impartially, he became unpopular with both parties. The rich felt disadvantaged by the reform. The poor, unable to hold excess in check, demanded a complete redistribution of landed property and the dividing of it into equal shares. However, despite these criticisms from both sides, Solon succeeded in restoring social peace. Furthermore, Solon brought about changes inconstitutional laws and this brought about "mighty shield against both parties and did not allow either to win an unjust victory" [Korab-Karpowicz, 2016]. He introduced a system of checks and balances which would not favor any side, but took into consideration legitimate interests of all social groups. In his position, he could easily have become the tyrant over the city, but he did not seek power for himself. After he completed his reform, he left Athens in order to see whether it would stand the test of time, and came back to his country only ten years later. Though in 561 Pisistratus forced himself into power and became the first in a succession of Athenian tyrants, and in 461 the democratic leader Ephialtes abolished the checks upon popular sovereignty, Solon's reform provided the ancient Greeks with a model of both political leadership and order based on impartiality and fairness. Justice for Solon is not an arithmetical equality: giving equal shares to all alike irrespective of merit, which represents the democratic concept of distributive justice, but it is equity or fairness based on difference: giving shares proportionate to the merit of those who receive them. The same ideas of political order, leadership, and justice can be found in Plato's dialogues (Koab-Karpowicz, 2016).

For Plato, like for Solon, the starting point for the inquiry about the best political order is the fact of social diversity and conflicting interests, which involve the danger of civil strife. The political community consists of different parts or social classes, such as the noble, the rich, and the poor, each representing different values, interests, and claims to rule. This gives rise to the controversy of who should rule the community, and what is the best political system. In both the Republic and the Laws, Plato asserts not only that factionalism and civil war are the greatest dangers to the city, more dangerous even than war against external enemies, but also that peace obtained by the victory of one part and the destruction of its rivals is not to be preferred to social peace obtained through the friendship and cooperation of all the city's parts [Korab-Karpowicz, 2016].

Peace for Plato is, unlike for Marxists and other radical thinkers, not a status quo notion, related to the interest of the privileged group, but a value that most people always look forward to. He does not stand for war and the victory of one class, but for peace in social diversity. "The best is neither war nor faction - they are things we should 
pray to be spared from - but peace and mutual good will" [Korab-Karpowicz, 2016]. Building on the pre-philosophical insights of Solon and his concept of balancing conflicting interests, in both the Republic and the Laws, Plato offers two different solutions to the same problem of social peace based on the equilibrium and harmonious union of different social classes. If in the Republic it is the main function of the political leadership of philosopher-rulers to make the civil strife cease, in the Laws this mediating function is taken over by laws [Korab-Karpowicz, 2016]. The best political order for Plato is that which promotes social peace in the environment of cooperation and friendship among different social groups, each benefiting from and each adding to the common good. The best form of government, which he advances in the Republic, is a philosophical aristocracy or monarchy, but that which he proposes in his last dialogue the Laws is a traditional polity: the mixed or composite constitution that reconciles different partisan interests and includes aristocratic, oligarchic, and democratic elements.

It is generally believed today that democracy, "government of the people by the people and for the people," is the best and only fully justifiable political system. The distinct features of democracy are freedom and equality. Democracy can be described as the rule of the free people who govern themselves, either directly or through their representatives, in their own interest. Why does Plato not consider democracy the best form of government? In the Republic he criticizes the direct and unchecked democracy of his time precisely because of its leading features [Korab-Karpowicz, 2016]. Firstly, although freedom is for Plato a true value, democracy involves the danger of excessive freedom, of doing as one likes, which leads to anarchy. Secondly, equality, related to the belief that everyone has the right and equal capacity to rule, brings to politics all kinds of power-seeking individuals, motivated by personal gain rather than public good. Democracy therefore can become corruptible unless practiced by the "right people". Otherwise, it opens gates to potential dictators, and can thus lead to tyranny. Hence, although it may not be totally applicable to modern liberal democracies, Plato's main charge against the democracy he knows from the ancient Greek political practice is that it is unstable, leading from anarchy to tyranny, and that it lacks leaders with proper skill and morals. It is the argument of Plato that Democracy must be mixed with competent and trust worthy leaders such as Solon. Plato argues further that if ruling a state is a craft, indeed statecraft, then politics needs expert rulers, and they cannot come to it merely by accident, but must be carefully selected and prepared in the course of extensive training. Making political decisions requires good judgment. Politics needs competence, at least in the form of today's civil servants. Who then should the experts be and why? Why does Plato in the Republic decide to hand the steering wheel of the state to philosophers?

For Plato, most people are corrupt and are fundamentally irrational, driven by their appetites, egoistic passions, and informed by false beliefs. If they choose to be just and obey laws, it is only because they lack the power to act criminally and are afraid of punishment [Korab-Karpowicz, 2016]. Nevertheless, human beings are not vicious by nature. They are social animals, incapable of living alone [Korab-Karpowicz, 2016]. Living in communities and exchanging products of their labor is natural for them, so that they have capacities for rationality and goodness. Korab-Karpowicz, (2016) orchestrated Plato's view that once political society is properly ordered, it can contribute to the restoration of morals. Plato does not see the best social and political order in a democratic republic. Opinions overcome truth in everyday life. Peoples' lives and the lives of communities are shaped by the prevailing beliefs. If philosophers are those who can distinguish between true and false beliefs, who love knowledge and are motivated by the common good, and finally if they are not only master-theoreticians, but also the masterpractitioners who can heal the ills of their society, then they, and not democratically elected representatives, must be chosen as leaders and educators of the political community and guide it to proper ends. They are required to counteract the destabilizing effects of false beliefs on society. Are philosophers incorruptible? In the ideal city there are provisions to minimize possible corruption, even among the good-loving philosophers. They can neither enjoy private property nor family life. Although they are the rulers, they receive only a modest remuneration from the state, dine in common dining halls, and have wives and children in common. These provisions are necessary, Plato believes, because if the philosopher-rulers were to 
acquire private land, luxurious homes, and money themselves, they would soon become hostile masters of other citizens rather than their leaders and allies [Korab-Karpowicz, 2016].

Korab-Karpowicz, (2016) points out that Plato's philosophers, among whom he includes both men and women, are not those who can usually be found today in departments of philosophy but are those initially chosen from among the brightest, most stable, and most courageous children. Thereafter, they go through a sophisticated and prolonged educational training which begins with gymnastics, music and mathematics, and ends with dialectic, military service and practical city management. They have superior theoretical knowledge, including the knowledge of the just, noble, good and advantageous, but are not inferior to others in practical matters as well. Being in the final stage of their education illuminated by the idea of the good, they are those who can see beyond changing empirical phenomena and reflect on such timeless values as justice, beauty, truth, and moderation. Goodness is not merely a theoretical idea for them, but the ultimate state of their mind. Plato assumes that a city in which the rulers do not govern out of desire for private gain, but are least motivated by personal ambition, is governed in the way which is the finest and freest from civil strife. Philosophers will rule not only because they will be best prepared for this, but also because if they do not, the city will no longer be well governed and may fall prey to economic decline, factionalism, and civil war. They will approach ruling not as something really enjoyable, but as something necessary [Korab-Karpowicz, 2016].

In Plato's view, philosopher-rulers do not derive their authority solely from their expert knowledge, but also from their love of the city as a whole and their impartiality and fairness. Their political authority is not only rational but also substantially moral, based on the consent of the governed. They regard justice as the most important and most essential thing. Also, what seems to stand firm is the basic idea that underlies philosophers' governance and that can be traced back to Solon: the idea of fairness based on difference as the basis of the righteous political order. A political order based on fairness leads to friendship and cooperation among different parts of the city.

In the ideal city all persons and social groups are given equal opportunities to be happy, that is, to pursue happiness, but not at the expense of others. Their particular individual, group or class happiness is limited by the need of the happiness for all. The happiness of the whole city is not for Plato the happiness of an abstract unity called the polis, or the happiness of the greatest number, but rather the happiness of all citizens derived from a peaceful, harmonious, and cooperative union of different social classes. The philosopher-rulers enjoy respect and contemplative leisure, but not wealth or honors; the guardian class, the second class in the city, military honors, but not leisure or wealth; and the producer class, family life, wealth, and freedom of enterprise, but not honors or rule. Then, the producers supply the city with goods; the guardians, defend it; and the philosophers, attuned to virtue and illuminated by goodness, rule it impartially for the common benefit of all citizens. The three different social classes engage in mutually beneficial enterprise, by which the interests of all are best served. Social and economic differences, i.e. departures from equality, bring about benefits to people in all social positions, and therefore, are justified. In the Platonic vision of the Republic, all social classes get to perform what they are best fit to do and are unified into a single community by mutual interests. In this sense, although each is different, they are all friends.

While it is not part of the primary focus of this paper to attempt a critical assessment of Plato's ideas, one opines that though Plato's philosopher kings with their attributes would bring appreciable level of good life to any society, the impression that Plato gives of these philosopher kings being flawless is not accurate. Similarly, Plato fails to explain the possibility of those who rule and have political authority becoming real; philosophers through divine intervention as he wants us to believe. Despite these problems with Plato's ideas, the fact still remains that to some extent, many of the conditions that Plato lamented about in his days are prevailing in $21^{\text {st }}$ century Nigeria and the nation can benefit from some of his recommendations. For example, Briggs (2018) rightly observes that election in Nigeria constitute serious flashpoints for riots, killings and conflicts. This according to him is so because political offices are considered to be so lucrative that those who vie for them and their supporters use whatever means at their disposal, fair or foul, to get elected. Thus, most election results are not only robustly disputed but also be- 
come the grounds for protests which in some cases degenerate into violence in which lives and properties are lost. Furthermore, despite the huge income Nigeria has derived from the sale of crude oil, and gas, estimated at N77.348 trillion between 1999 and 2016, Nigeria has remained a poor country with a GDP per capital of 2412.41 US dollars in 2017. The country has been unable to utilize the funds so obtained to satisfactorily improve the lives of its citizens and to develop the economy properly. The resultant high unemployment rates especially among youths and professional groups have led to frustration, desperation and recourse to crime and criminality [Briggs, 2018].

\section{Plato on Political Stability: What Nigeria Stands to Benefit}

The history of Nigeria since independence shows that the nation has experienced series of turbulent civilian administrations, civil wars, military coup d'états, intense violence arising from political activities founded on ethnic and religious sentiments [Wogu et al., 2016]. The various regime changes and switch from military to civilian administration and from military to military and then later from military to civilian administrations have turned the Nigerian political arena into a political laboratory where for over 50 years of its existence as an independent nation, Nigeria still strives to find her feet on the path that sets most independent nations on the path of sustainable political and economic growth [Wogu et al., 2016].

As a result of leadership challenges in the nation, unemployment is becoming unprecedented; many of those who are employed in public service do not get paid regularly while many of those who are paid regularly only receive varying percentages of their normal salary. A total number of 52 million citizens within the economically active population of Nigeria is jobless and this figure consists mostly of newly qualified university graduates [Longe, 2017]. Crime waves are on the increase and the level of is insecurity is very high. Nigeria has been on the global crime map since 1980's [Adebayo, 2013]. Poverty level in the nation isalarming, so is the gap between the rich and the poor increasing on daily basis.

Nigeria has in recent times been referred to as the fastest growing economy on the African continent. Ironically, the country also harbors some of the poorest people in the world with as many as $69 \%$ of the population which is about 112.47 million, living below the poverty line ["Corruption and Poverty in Nigeria", 2015]. Given the country's enormous resources, it is puzzling that such a huge portion of the populace lives in poverty. The vast incidence of poverty in the midst of plenty has been severally linked to the endemic corruption in the country, as it involves the massive stealing of resources that would have otherwise been invested in providing wealth-creating infrastructures for citizens ["Corruption and Poverty in Nigeria", 2015]. The integrity of the judiciary in the nation is not encouraging as justice has almost been handed over to the dogs. In the nation, Corruption is more or less a culture and there is lack of political will at the highest level of government to reduce or stop it. Nigeria scores high in the corruption perception index and scores low in the Human Development Index implying that because the incidence of corruption is high, investment in citizens' welfare is low. Many of the graduates of the nation's institutions have nothing to show when it comes to the issue of character and patriotism. That the condition in the nation is similar to a large extent to what the situation was in Athens of Plato's time is an understatement. As is to be expected, in a nation where the vices mentioned above are not only present but pronounced, almost all the features of Plato's political theory that are supposed to be present in a good society which desire political stability are absent in Nigeria. These features have already been discussed in the earlier paragraphs. It stands to reason therefore that these features be considered by relevant authorities in Nigeria so as to give the nation a better sense of direction towards achieving political stability, development and a better life for the citizens. Cursorily, some of these features are:

- Political offices should be made and seen as positions of utter sacrifice for the good of the society. Therefore the salary attached to such offices should be relatively unattractive and those who chose to go into such offices should be not be given any immunity that can prevent them from being probed while in office. Those who occupy such offices should as a matter of compulsion be probed upon leaving office.

- Politicians holding public offices should be placed on civil service salary grade levels.

- The practice of giving stupendous gifts such 
as cars, houses to politicians holding public offices should be stopped while the security allowance being given to State governors should be drastically reduced. This will further stripe political offices of the attractiveness that is making people desperate to occupy such offices.

- Legislators should be made to serve on part time basis. This will make more money available in government coffer that can be spent in alleviating the sufferings of the masses.

- Only those who have practical and obvious record of consistent devotion to public interest should be allowed into position of leadership. This will go a long way in ensuring the credibility of the leaders.

- Politics should not be made an all comers job or an avenue of getting rich quickly. While wealth should not be made a necessary condition for vying for political office. A modality should be put in place for sifting those who intends to go into politics in order to ensure that indeed they are going in for the sake of sacrificing for the common good. Those who succeed in the screening exercise should thereafter be given special training to make model politicians out of them.

The above features if imbibed as part of national life will put a permanent end to the perennial problem of riots, killings and conflicts that characterize elections in Nigeria as political offices are considered to be so lucrative that those who vie for them and their supporters use whatever means at their disposal, fair or foul, to get elected. Furthermore, with these features in place, only those who are capable and are genuinely willing to serve the nation will have access to position of leadership in the country. Some other features are:

- The purpose of education should among other things be to help students develop their character, the capacity to do good and the willingness to serve the nation.

- The educational system among other things should be specifically designed to train leaders and followers to place civic welfare above everything else in the real sense of the word.
- Each member of the society should be given the opportunity to be able to occupy appropriate place in the society by merit without having to resort to any "godfather" and should be appropriately rewarded for services rendered.

- Justice should be seen as being truly dispensed without fear or favor and for the common good of the entire society.

One of the major factors fueling political instability in Nigeria is the reluctance of some of the citizens to accept the Nigerian state [Briggs, 2018]. After living together for more than ten decades, many Nigerians still do not see themselves as belonging to the same country. Their loyalty to the country is tenuous and they associate more with their tribe than the country. Many of the citizens lack a sense of national pride and are not patriotic in the least. Similarly, instead of respecting individual religious beliefs and building on diversity that ethnicity and religion offer to a secular state, ethnicity and religion have often been used by majority of the political class, persons in authority, the elite and the well to dos to set Nigerians against one another. Religious differences, especially between Muslims and Christianity together with ethnicity between the various tribes in the country, have been behind the many communal conflicts that have taken place in Nigeria. In the same vein, corruption has caused the wealth of the entire nation to be in the hands of very few individuals resulting into the inability of the country to develop as it should and causing high unemployment, desperation, crime and criminality. These factors that enhance political instability in the country will be addressed if the features highlighted above are recognized and made part and parcel of the national life.

\section{Conclusion}

From the earlier discussion, it is obvious that the socio-political malaise that Plato sets out to cure in Athens of his days resemble to a large extent what characterize twenty first century Nigerian Society. It follows therefore that Nigeria can borrow a leaf from the preceding analysis of Plato's theoretical framework in making the nation politically stable. It is important to note that there are countries in the contemporary world with stable polity and their stability can be rightly traced to the fact that most of the values which Plato emphasized in his theoretical framework are part of their national 
lives. Some of these countries according to Briggs (2018) are discussed.

\section{Botswana}

Botswana is a small landlocked country with a little over 2 million persons located in Southern African Region. It became independent in 1966 and has since then gotten a reputation for being a model of stable and well run democracy in Africa. In its 2017 global ranking, Transparency International placed Botswana with a score of 61 out of 100 as the $34^{\text {th }}$ country with least Corruption Perceptions Index (CPI) in the world and the $1^{\text {st }}$ in Africa. Over the years, the country has developed itself from one of the poorest to an upper middle income one. The country has no history of any major uprising against the State, it invest heavily in education and has a record of good leadership since independence. For example, Festus Mogae served as the county's $4^{\text {th }}$ vice president $(1992-1998)$ and later as its $3^{\text {rd }}$ president (1998-2008) and won the prestigious Ibrahim Prize for Achievement in African Leadership in 2008 for his exemplary leadership, especially his efforts at eradicating poverty and unemployment.

\section{Tanzania}

Tanzania is located in East Africa with a population of about 60 million people who speak over 130 languages. The country has a record of having been led by one of African's most respected leaders; the late Mwalimu Julius Nyerere, who amongst other things, successfully suppressed ethnicity in his bid to establish a national identity for the country. The current President, the $5^{\text {th }}$; Dr John Magufuli has established a very strong aversion for corruption. While Tanzania is one of the most ethnically diverse countries in Africa, altercations a result of ethnic divisions are very rare and since 1964, the country has the record of having displayed more political stability than most other African countries [Bjerk, 2015].

\section{Malaysia and Singapore}

These two countries located in Southeast Asia have strong affinity with each other. They were both colonized by Britain and have since independence grown to become very successful with some of the best global economic indices with GDP that have grown by an average of $6.5 \%$ for over 50 years. Education and health are highly subsidized and are regarded as being among the best in the world. The two countries have enjoyed good polity and leadership. Particularly, Lee Kuan Yew who was the Prime Minister of Singapore from 1959 to 1990; a period of eight terms and Mahathir Mohamad who was the Prime Minister of Malaysia from 1981 to 2003 recorded very rapid economic transformation [Briggs, 2018].

Briggs (2018) identifies some common factors that enhanced political stability in the countries mentioned above. These factors include:

- Institution of social amenities that enhanced the prospects of a better life for the poor. Of these, education and health were given priority. These amenities were either free or heavily subsidized at various levels and were of such good quality, that some of them were considered among the global bests. Literacy rates in these countries are among the highest in the world and health and education industries are huge. They offer employment opportunities to the indigenes thereby reducing to the barest minimum youth unemployment with its associated frustration and hopelessness.

- In all instances, each of these countries had a leader at some time that properly harnessed the resources of the country and channel them to national development that benefitted all segments of the society. In many instances, their leaders were not ostentatious but lived within their means and their governance attracted global recognition.

- The rule of law prevailed at all times. Cases of impunity in which highly placed individuals took laws into their hands and subverted the rule of law were uncommon.

- Sincere efforts were made by those authority to meet the needs of their people through governance that was transparent, inclusive, people oriented and largely devoid of corruption.

- The military did not at any time, interfere in the governance process of these countries and the political establishments were allowed to learn from their own mistakes and to come up with better and more stable system with the passage of time.

These common factors that made the countries politically stable are all embedded in Plato's theoretical framework. This goes a long way to drive 
home the fact that Nigeria can learn a thousand and one lessons from the preceding analysis of Plato's theoretical framework. Specifically, just as it is embedded in Plato's theoretical framework, the examples of the countries cited in the preceding paragraphs confirm the fact that if Nigeria is to go far at all, she must admit her leadership challenges and confront it headlong.

\section{References}

Adebayo, A.A.(2013). Youth unemployment and Crime in Nigeria: A nexus and Implications for national development. International Journal of Sociology and Anthropology. Vol 5 (8).pp. 350357, DOI: 10.5897/ijsa2013.0452.

Bamisaiye, R.(1998). What is Political Stability, and how can we educate for it? Being the Text of a Lead Paper presented at the Annual Conference of the Philosophy of Education Association of Nigeria, (PEAN), University of Jos, November 3-6.

Bjerk, P. (2015). Building a peaceful Nation: Julius Nyerere and the Establishment of Sovereignty in Tanzania, 1960 - 1964. Rochester, NY: Rochester University Press pp.17

Briggs, N. (2018). Education for Political Stability in Nigeria. $38^{\text {th }}$ Annual Conference of Philosophers of Education Association of Nigeria. 2326 October. University of Port-Harcourt, Nigeria.

Brumbaugh, R.S.(1974). "Plato", The Encyclopedia Americana. International Edition, New York, 1974. pp.231

Castle, E.B.(1964).Ancient Education and Today. Harmondsworth, Middlesex, Penguin Books Ltd. pp.60.

Corruption and Poverty in Nigeria (2015). Corruption and Poverty in Nigeria. Action Aid publishers.Garki, Abuja, Nigeria

Dewey, J. (1966). Democracy and Education. The Free Press paperback, London. pp. 88.

Elechi, G.E. (2012). Plato's Socio-Political Philos- ophy: A veritable Prescription for Achieving the Seven Point Agenda in Nigeria for National Development. Journal of Economics and Sustainable Development. Vol 3, No 11.pp. 136-140.

Hare, T.M. (1999). Plato. Oxford University Press, pp.113

Jane, D. (1994). Plato's Meno in Focus. London: Routledge. pp.5

Korab- Karpowicz, W.J. (2016). History of Political Philosophy: Greek Political Thinkers from Thucydides to Locke. New York: Routledge. pp. 16-33.

Longe, O. (2017). Graduate Unemployment: Causes, Consequences \& Remediable Approaches. American Journal of Contemporary Research. Vol. 7, No 4, pp. 63-67.

Monroe, P. (1957). A Text Book in the History of Education. The Macmillan Company. New York. pp. 134

Murphy, M. (2015). Plato's Philosophy of Education and the Common Core debate. Association for the Development of Philosophy Teaching (ADOPT). Spring Conference Chicago,IL. De Paul University, April 25.

Plato (1955). The Republic, the Penguin Classics translated with an introduction by H.D.P.Lee. London and Tonbridge, The whitefriars Press Ltd

Sabine, G.H. (1973). A History of Political Theory. Thomas Landon Thorson (Hinsdale, Illinois, Holt, Rinehart and Wiston, Inc.,) $4^{\text {th }}$ edition, pp.56

Smith, L. Glenn, \& Joan, K. Smith. 1994. Lives in Education: A Narrative of People and Ideas. $2^{\text {nd }}$ ed. New York: St. Martin's Press.

Wogu, I.A.P, Olu-Owolabi, F.E., Sholarin,M. Elegbeleye, A., Akoleowo, V.O., Olukotun, A, Folarin, S. (2016). Plato's Theory of Education and the Quest for Sustainable Development in Nigeria. $2^{\text {nd }}$ Biennial Conference of the Faculty of Arts and Education Lead City University, Ibadan, Nigeria. November 28 - December $1^{\text {st }}$. 